International Journal of Instruction

e-ISSN: 1308-1470 • www.e-iji.net

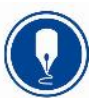

October $2018 \bullet$ Vol.11, No.4

p-ISSN: 1694-609X

pp. 593-606

Received: 12/04/2018

Revision: 02/07/2018

Accepted: 06/07/2018

\title{
Open Inquiry in Facilitating Metacognitive Skills on High School Biology Learning: An Inquiry on Low and High Academic Ability
}

\author{
Irwandi Rahmat \\ Science Education Department, Faculty of Education, Naresuan University, Thailand \\ irwandirahmat12@gmail.com
}

Skonchai Chanunan

Science Education Department, Faculty of Education, Naresuan University, Thailand

$\mid$

Learning model and academic ability are important considerations in developing students' skills including metacognitive skills in biology learning. The study aimed to investigate the effect of open inquiry on the metacognitive skills of students in different academic abilities. The study was quasi-experimental research, using the equivalent post-test only with control group design. The subjects of the experiment comprised 60 eleventh grade students. The samples were randomly assigned in a $2 \times 2$ factorial design. Two learning models were compared: open inquiry and conventional models, and two academic abilities: high and low. The students' metacognitive skill was measured by an essay test integrated with academic achievement measurement, as well as an application of a learning journal as selfassessment. The result of a 2-way ANOVA test confirmed the metacognitive skills of students with high and low academic abilities in experiment class was significantly higher than those students in control class, but not for their interactions. Accordingly, the implementation of inquiry-based learning appears to be an effective strategy among students with different academic abilities.

Keywords: metacognitive skills, retention, academic ability, open inquiry, and learning journal

\section{INTRODUCTION}

In this era, we are constantly required to acquire various skills and competencies as well as improving those of what we have had before. Nevertheless, some of those skills and competencies are not necessarily all new since they have been required since previous eras. In addition, the expected thinking skills in globalization era are the level of thinking about thinking process, which involves Higher-Order Thinking known as metacognition. This thinking level has become an avowed predictor of learning performances (Brown \& DeLoache, 1978; Glaser, 1990; Veenman \& Elshout, 1994). The term of metacognition is defined as knowledge about our own thinking process

Citation: Rahmat, I., \& Chanunan, S. (2018). Open Inquiry in Facilitating Metacognitive Skills on High School Biology Learning: An Inquiry on Low and High Academic Ability. International Journal of Instruction, 11(4), 593-606. https://doi.org/10.12973/iji.2018.11437a 
(Woolfolk, 2014). Metacognitive skills refer to an executive control process, because they may purposely be used to regulate cognition. The executive control process means that processes such as rehearsal, selective attention, and elaboration influence the encoding, storage and retrieval of information in the memory (Woolfolk, 2014). An expansion of students' metacognitive skills has been recognized as a valuable educational target as the skills that can assist students to become self-regulated learners (Eggen et all.,1996), because they can manage for themselves including their brain (Peters, 2000). Self-regulated learners are responsible for the progress of their learning and adapt their strategies to reach a mastery learning (Anderson et al., 2001).

However, some developing countries including Indonesia are still in low educational rating. Indonesia is known as an island country with a large population. This condition leads the educational deployment information not to be equivalent. There were many islands that are still in an apprehensive educational condition including Sulawesi Island. The learning involvement process of various educational levels in Sulawesi Island, Indonesia still emphasizes to focus on the cognitive aspect. The pattern is constantly dominated by teacher-centred learning paradigm and non-constructivism so that the effectiveness and construction of learning process are in a deficient condition. The empowerment of learners' potential has not been implemented maximally that induces the learning process to become meaningless. These situations lead the students to follow the learning process, which is not interesting for them. This habit is also believed to produce a more passive learner where the students have a less ability to manage their brain or control their learning process. The low ability of self-control in thinking process means that the students have low metacognitive skills, which is highly related to a selfregulated learner. In addition, the teacher-centred approach has been recognized as an incapable approach to develop various skills of students including metacognitive skills. The previous studies have found that the metacognitive skills of students in Indonesia were in apprehensive level (Prayitno, 2011; T. Suratno, 2009). Similarly, the students' metacognitive skills were still low in both of the elementary school students (Danoebroto, 2008) and the high school students (S. Suratno, 2011). This shape shows that the students have an adversity with arranging and gauging their thinking advancement. This is being a wretched situation, as the metacognitive skills are a strong predictor of cognitive development. However, metacognitive skill is a simple strategy; it is powerful to improve the students' thinking and learning abilities. The lack of metacognitive and writing development is feared that can affect the low quality of education in Indonesia.

Other than that one notable consideration in the learning process is an academic ability, in which students obtain the knowledge or ability from the process of problem-solving or test in the learning activity (Cangelosi \& Schaefer, 1991). It also becomes an important consideration in determining a teaching strategy and recording the progress of students' learning. Bransford et all., (2000) and Arikunto (2001) stated that students with different academic abilities have different understandings before obtaining learning material from class, therefore students who follow the tests can be classified into two groups, namely the student group in high ability (upper group) and the group student in low ability (lower group). 
In Sulawesi Island, Indonesia, some schools require a minimal passing level of national tests before accepting new students. The pattern induces the polarization, which classifies schools into high, medium and low academic ability schools. In their study considering the different passing levels for different schools in Indonesia, Antika et all., (2013) found that although most of the students passed the standard score than fail, their scores are generally close to the minimum passing level. Another situation was that some of the high school teachers who are faced with students of diverse academic ability trend to focus on those with low academic ability. In tests, for instance, they devise test papers with multiple-choice questions and possible essay type tests which are dominated by $\mathrm{C} 1-\mathrm{C} 3$ cognitive level questions, suggesting that the guidance of the learning system in the classroom concentrates on less able students. It is therefore important to notice that students with high and low academic abilities are to be taken into account before selecting strategies, evaluation instruments and other forms of instruction to improve their skills including metacognitive skills.

In addition, inquiry-based learning is appropriate with the constructivism approach which refers that the idea and knowledge might not come immediately from the teacher to the student, but it is fervently developed by students (Zion \& Mendelovici, 2012). Students need to adapt to this learning process, which refers to the recognising, promoting and instructing the role of metacognition, as metacognitive skills are side of the "learning to learn' skills that can be linked to recent learning situation, in school or out of school (Kuhlthau, 2010). Through reflecting during inquiry-based learning activity, students have opportunities to investigate and comprehend both affective and cognitive portions of "learning to learn"(Kuhlthau, 2010). There are various kinds of inquiry-based learning/teaching embracing from a more teacher-directed structure and guided inquiry to open inquiry which focuses on student directed learning (Council, 2000). Open inquiry is the most complex inquiry-based learning level as it imitates and reflects the experimental work and research types that is implemented by a scientist as well as empower high order thinking capability covering questioning, designing, critical a logical thinking and reflection (Zion \& Mendelovici, 2012).

In open inquiry, the teaching activity develops a learning community of both teacher and student that are the crucial aspects of a successful of inquiry process (Zion \& Slezak, 2005). An application of open inquiry leads students to split, understand and ride into practice as a creative and positive life-long thinking character (Knodt, 2009). Students who used open inquiry performed better and were more satisfied as they gained advantages from implementing the project, and performing activities actively (Roth, 2012). In addition, open inquiry required students to learn independently rather than expecting all information from the teachers. Yerrick (2000) examined the effect of open inquiry instruction to low achievement high school students. The result showed that those students, who were academically less able, might find that they benefit from the use of open inquiry instruction, though they need to undergo a longer period of adjustment. In summary, the application of open inquiry learning encourages students to be active learners, enable them to improve their skills including metacognitive skills. Incorporation of metacognitive questions can also be presented on student lessons, lectures and assignments to help them to be more self-reflective (Jonassen, 2011). 
In this study, the researcher tried to investigate the effect of open inquiry on the metacognitive skills of students in low and high academic ability. The expectation was that open inquiry supported would provide a significant improvement of students' metacognitive skills on both high and low academic abilities.

\section{METHOD}

\section{Samples}

This study has been conducted in the first semester of the 2017 academic year. The sample consisted of science students in grade $11^{\text {th }}$ State senior high school 14 of Makassar, South Sulawesi Indonesia. The sample consists of 60 students with different academic abilities divided in 2 classes (control and experiment). All students were in 16 to 17 years old grouped to high and low levels of academic ability. Students with high academic ability $(n=30)$ and low academic ability $(n=30)$ were placed to 15 high academic abilities and 15 low academic abilities in experiment class and the others were in control class.

\section{Design}

The study was quasi-experimental research using the equivalent post-test only with control group design. The students were randomly assigned on the condition of a 2 × 2 factorial design (see Fig.1), where one factor was the provision of open inquiry (high and low academic abilities) and another factor was a provision of conventional method (high and low academic abilities).

Table. 1

Research blueprint of factorial experiment $2 \times 2$

\begin{tabular}{lcc}
\hline \multirow{2}{*}{ Academic ability } & \multicolumn{2}{c}{ Method (S) } \\
\cline { 2 - 3 } & Open Inquiry & Conventional \\
& $(\mathbf{E})$ & CH (n: 15$)$ \\
\hline High (H) & EH (n: 15) & CL (n: 15) \\
Low (L) & EL (n: 15) &
\end{tabular}

EH: High academic ability in experiment group

EL: Low academic ability in experiment group

CH: High academic ability in control group

CL: Low academic ability in control group.

\section{Experimental Procedures}

The experiment was conducted on the eleventh-grade students studying at State Senior High School 14 of Makassar, South Sulawesi Indonesia. The treatment was seven periods of biology learning excluding post-test. The first step was grouping. There were four groups that were investigated namely: high academic ability in experiment group (n: 15), low academic ability an experiment group (n: 15), High academic ability in a control group (n: 15) and low academic ability in a control group (n: 15). Both experiment and control classes contained one high and low group. 
The second phase was validation process. There were five educational experts who validated the lesson plan of open inquiry along with the instruments and learning journal prompts that have been developed by researcher. The third step was a treatment process. In this step, the researcher was as a teacher. In experiment class, the students were performed using open inquiry followed by learning journal. In control class, the students were taught using conventional method. The third step was post-test. In this step, the researcher examined the metacognitive skills of students after seven periods of learning through essay test integrated with achievement test. This step was conducted 3 days after the last meeting period.

\section{Instrument}

Metacognitive skills were measured through essay test integrated with achievement test. The essay questions used in examining metacognitive skills referred to cognitive levels of C2 to C5 from Bloom's taxonomy revised by Anderson \& Krathwohl. The essay test was applied supported by a specific rubric as the scoring process using 0 to 7 rating scales designed to measure metacognitive skills developed by Corebima (2009). The certain rubric is designed in connection to the categories of knowledge about cognition (declarative knowledge, procedural knowledge and conditional knowledge), as well as the categories of regulation of cognition (planning, information management strategies, comprehension monitoring, debugging strategies and evaluation). Because of limited scope, some categories of the rubric include knowledge of cognition and regulation of cognition. The knowledge about cognition category that cannot be denoted in the rubric designing is conditional knowledge, while the regulation of cognition categories that cannot be mentioned are information management strategies and debugging strategies.

In addition, the study by Corebima (2009) found the parameters of the rubric he has developed related to declarative knowledge, conditional knowledge, information management strategies, comprehension monitoring and evaluation. Those parameters were the answers in own sentences, systematic answers, logical answers, correct grammars, answer reasons, and correctness. Below is the scoring rubric of metacognitive skills developed by Corebima (2009). 
Table 2

Score Rubric descriptor for Measuring Metacognitive Skill Score Integrated to Essay Test of Achievement Test

\begin{tabular}{|c|c|}
\hline Score & Description \\
\hline 7 & $\begin{array}{l}\text { The answer is written in their own sentences. The order of answer is harmonious as } \\
\text { well as systematic. The answer is logic in correct grammar, supported by explaining } \\
\text { reason (analytic, evaluative, or creative explanation), and the answer is correct. }\end{array}$ \\
\hline 6 & $\begin{array}{l}\text { The answer is written in their own sentences. The order of answer is harmonious as } \\
\text { well systematic. The answer is logic in less correct grammar, supported by explaining } \\
\text { reason (analytic, evaluative, or creative explanation), and the answer is correct. }\end{array}$ \\
\hline 5 & $\begin{array}{l}\text { The answer is written in their own sentences. The order of the answer is } \\
\text { less/inharmonious as well as less/unsystematic. The answer is less/ not logic in less } \\
\text { correct grammar, supported by explaining reason (analytic, evaluative, or creative } \\
\text { explanation), and the answer is correct. }\end{array}$ \\
\hline 4 & $\begin{array}{l}\text { The answer is not written in their own sentences. The order of answer sentences is } \\
\text { harmonious as well as systematic. The answer is logic in correct grammar, supported } \\
\text { by explaining reason (analytic, evaluative, or creative explanation), and the answer is } \\
\text { correct. }\end{array}$ \\
\hline 3 & $\begin{array}{l}\text { The answer is not written in their own sentences. The order of answer sentences is } \\
\text { less/unharmonious as well as less/unsystematic. The answer is less/not logic, in less } \\
\text { correct grammar, supported by explaining reason (analytic, evaluative, or creative } \\
\text { explanation), and the answer is correct. }\end{array}$ \\
\hline 2 & $\begin{array}{l}\text { The answer is not written in their own sentences. The order of answer sentences is } \\
\text { less/unharmonious as well as less/unsystematic. The answer is less/not logic, in less } \\
\text { correct grammar, not supported by explaining reason (analytic, evaluative, or creative } \\
\text { explanation), and the answer is less correct. }\end{array}$ \\
\hline 1 & $\begin{array}{l}\text { The answer is not written in their own sentences. The order of answer sentences is } \\
\text { less/unharmonious as well as less/unsystematic. The answer is less/not logic, in less } \\
\text { correct grammar, not supported by explaining reason (analytic, evaluative, or creative } \\
\text { explanation), and the answer is incorrect. }\end{array}$ \\
\hline 0 & There is no answer at al. \\
\hline
\end{tabular}
Analysis

A 2-way ANOVA test was carried out to analyse the data of this study. Statistical analysis was assisted with the software SPSS 20 for Windows, which was applied to the significant extent of 0.05 ( $<<0.05)$. The advanced test was executed by the Least Significant Difference test (LSD). Before conducting hypothesis test by using 2-way ANOVA, the assumption test including homogeneity and normality test of data were examined. For normality test One-Sample Kolmogorov-Smirnov was used and for the homogeneity test Leven's Test of Equality of Error Variances was used.

\section{FINDINGS}

The result of the study describes the students' metacognitive skills through variance analysis (2-Way ANOVA). The description of metacognitive skills was in the form of a mean score of post-test based on group and academic ability of students. Figure 1 presents these results as follows. 


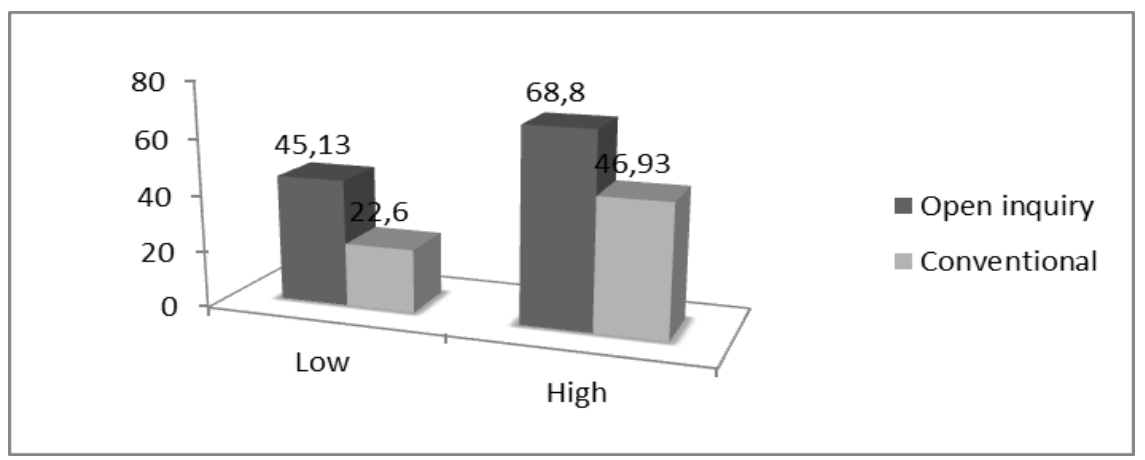

Figure 1

The comparison graphic of students' metacognitive skills based on learning models and academic ability

Figure 1. shows that: 1) in low academic ability groups, the mean post-test score of the students in an open inquiry class is $99.69 \%$ higher than the mean post-test score of students in conventional class. 2). In high academic ability groups, the mean post-test score of the students in open inquiry class is $46,60 \%$ higher than the mean post-test score of students in conventional classes. Below is the result of 2-way ANOVA test.

Table 3

2-way ANOVA test result of the effect of learning model and academic ability to metacognitive skills

\begin{tabular}{llll}
\hline Source & df & F & Sig. \\
\hline Corrected Model & 3 & 667.102 & .000 \\
Intercept & 1 & 15754.689 & .000 \\
Acaddemic_Abilities & 1 & 922.702 & .000 \\
Group & 1 & 1078.395 & .000 \\
Acaddemic_Abilities & $*$ & .208 & .650 \\
Group & 1 & & \\
Error & 56 & & \\
Total & 60 & & \\
Corrected Total & 59 & & \\
\hline
\end{tabular}

The information is illustrated as follows

\section{The effect of learning models on metacognitive skills}

The F score from the learning model (group) is 1078.395 with $\mathrm{p}$ value $0.000<a(0,05)$. Hence, $\mathrm{H} 0$ can be rejected and $\mathrm{Ha}$ is accepted. This means that the learning model had a significant effect on students' metacognitive skills. However, the present study only consisted of two groups so that it is not necessary to apply the Least Significant Deference (LSD) test. Table 4 shows the difference of metacognitive skills in each model. 
Table 4

The mean of metacognitive skill on every learning model

\begin{tabular}{crrrr}
\hline Group & Mean & Std. Error & \multicolumn{2}{c}{$95 \%$ Confidence Interval } \\
\cline { 4 - 5 } & & & Lower Bound & Upper Bound \\
\hline Control & 33.867 & .517 & 32.831 & 34.902 \\
Experiment & 57.867 & .517 & 56.831 & 58.902 \\
\hline
\end{tabular}

Based on table 2, it can be stated that the group which was carried out using open inquiry learning has a higher mean than the group that was treated using conventional methods. This study indicated that the metacognitive skills of students who were taught using open inquiry were $72.72 \%$ higher than students who were treated using the conventional model. Open inquiry encouraged students who were independently involved in biology learning activities. Students were expected to determine the problem and observe and evaluate what they have done independently as a process of empowering their metacognitive skills. Therefore, open inquiry has high potential to facilitate metacognitive skills to students.

\section{The effect of academic ability on metacognitive skills}

The F score from the academic ability is 922.702 with $\mathrm{p}$ value $0.000<a(0,05)$. Hence, $\mathrm{H} 0$ can be rejected and $\mathrm{Ha}$ is accepted. It means that open inquiry has a significant effect on the academic ability of students' and their metacognitive skills. However, the present study only consisted of two groups so that is not necessary to apply Least Significant Deference (LSD) test. Table 2 shows the difference between metacognitive skills in each academic group.

Table 5

The mean of metacognitive skill on each academic ability group

\begin{tabular}{lrrrr}
\hline Academic Abilities & Mean & Std. Error & \multicolumn{2}{c}{ 95\% Confidence Interval } \\
\cline { 4 - 5 } & & & Lower Bound & Upper Bound \\
\hline High Academic Abilities & 56.967 & .517 & 55.931 & 58.002 \\
Low Academic Abilities & 34.767 & .517 & 33.731 & 35.802 \\
\hline
\end{tabular}

Table 3 indicates that students with high academic ability had higher mean score contrasted to students with low academic ability. Accordingly, metacognitive skill of the students with high academic ability is $63.85 \%$ higher than low academic ability. The 2way ANOVA test result shows that there is a significant difference between students with high academic ability and low academic ability.

The effect of interaction between learning model and academic ability on metacognitive skills

The F score of the interaction between the learning model and academic ability is 2.166

with a p value $.208>a(0,05)$. Hence, $\mathrm{H} 0$ is accepted and Ha can be rejected. It means that there is no significant effect from the interaction between academic ability and the learning model on students' metacognitive skills. However, the present study includes 
four groups, so it is necessary to apply the Least Significant Deference (LSD) test. Table 2 shows the result of LSD analysis

Table 6

The mean of metacognitive skill on interaction group

\begin{tabular}{clccc}
\hline No & Group & Mean & \multicolumn{2}{c}{ Notation } \\
\hline 4 & Conventional - low & 22.60 & d & \\
3 & Conventional - High & 45.13 & & \multicolumn{2}{c}{ c } \\
2 & Open Inquiry - Low & 46.93 & \multicolumn{2}{c}{ b } \\
1 & Open Inquiry - High & 68.80 & & $\mathbf{a}$ \\
\hline
\end{tabular}

1: High academic ability in open inquiry group

2: Low academic ability in open inquiry group

3: High academic ability in conventional group

4: Low academic ability in conventional group.

The result shows the following information, 1) the students' metacognitive skills in conventional -low academic ability group were the lowest scoring of the four groups. 2) The students' metacognitive skills in open inquiry-high academic ability group were significantly the highest scoring among the other interactions. 3) There was no significant difference in students' metacognitive skills between low academic ability in open inquiry group and high academic ability in conventional group. The metacognitive skills of students in conventional-high academic ability group were $99.60 \%$ higher than conventional-low academic ability group. In the open inquiry-high academic ability group, the score was $46.60 \%$ higher than the open inquiry-low academic ability group.

\section{DISCUSSION}

Open inquiry encouraged students who were independently involved in biology learning activities. In addition, the steps in open inquiry learning model had covered the aspects of metacognitive skills. The process of determining the problems, creating core problem, making a hypothesis, and planning the problem solving or experiment design were determined as planning aspect in metacognitive skills. The process of doing an experiment, observing, collecting and analyzing data was determined as monitoring aspect in metacognitive skills. The last activity was providing an inferential of learning, which was determined as evaluation aspect in metacognitive skills.

In planning phase, the students explore their understanding to find out the previous knowledge that they have, which will assist them in completing the task, they know what they will do to help for completing the task, and purposing the time management during planning activity. In open inquiry activity, the students were working on the metacognitive skill sheets, which push them to use their prior knowledge. The prior knowledge points to the student knowledge from materials that they have learned. The students ask themselves about the information that they should know and how much time is needed from the question provided to solve the problem. In monitoring phases, the students move to solve the problems that they have listed, remember the important information, and verify their work. Throughout, the students in monitoring activity will ask her/him related to the important information that should be remembered and the 
activity they should do to complete their work or solve their problem. In evaluation activity, the students will do an inspection on the suitability between their knowledge and the way to solve the problem. They can reflect themselves about how well they have worked on learning, which indicates student expressiveness in specifying the way to solve the problem on previous knowledge.

In open inquiry class, the teacher only controlled the availability of materials, and gave initiation materials so that students obtained less guidance from teacher, yet they were still in under control. Students were expected to determine the problem and observe and evaluate what they have done independently as a process of empowering their metacognitive skills. Therefore, open inquiry has a high potential to facilitate metacognitive skills for students. Moreover, the implementation of inquiry learning refers to learning principles based on constructivism namely: learning by doing, learning to develop social ability or cooperation and learning to expand problem-solving skills. There were metacognitive skill improvements through inquiry based learning (Bahri, 2018) . Zion and Mendelovici (2012) stated that inquiry learning is proper with the constructivism approach, which the idea and knowledge did not came directly from the teacher to the learner, but the learner develops it. Zion et al mentioned that open inquiry imitates and reflects the experimental work and research implemented by a scientist. It empowers high order thinking capability covers a variety of skills including metacognitive skills.

In open inquiry, students not only studied but also actively created planning strategies, monitoring and evaluating their own learning. All components of open inquiry can direct and develop the metacognitive skills of students as well as induce active and independent learners. Students obtained the meaning of their learning through observation, inference and interaction with others. Generalization is not limited, and the knowledge can be applied in other areas, e.g. the study of the cell in biology, can be expanded and applied in other areas of study. Bonnstetter (1998) suggested that open inquiry facilitated students to identify problems and design inquiry processes. Students were motivated to empower their metacognitive skills through expressing their ideas and testing them, intensifying critical thinking, finding information, analysing argument, synthesizing new ideas, utilizing their impressions to solve problems and generalizing data, so that the learners assign the study as part of their own self (Chickering \& Gamson, 1987).

As can be seen in table 3, the metacognitive skills of students with high academic ability are higher than students in low academic ability. Students who have high academic ability were more adept than students in low academic ability. Although both high and low ability groups improved in their scores, those with higher ability still performed better than those with lower ability. It happened because thinking ability is a basic competence in strategy development, doing experiments, problem solving and also affects the intellectual development of students. Moreover, students with high academic ability will perform better in high order thinking than students with low academic ability (Lyman \& Harvey, 1988). Metacognitive skill is closely related to thinking ability so that if the learners have better thinking ability, they may have metacognitive skills. 
Another result from two-way ANOVA test shows that there was no significant effect between the academic ability and learning model toward students' metacognitive skills. Although, high ability group in open inquiry class has higher mean score than conventional, both treatments make their classes easier. For low academic ability groups, whether the conventional or the open inquiry methods were used, the students still had some difficulty in mastering the relevant material. The interaction between learning strategy and academic ability generates no effect on students' gratification in learning (Lee et all., 2002). In open inquiry class, the teacher only controlled the availability of materials and gave initiation materials so that students obtained less guidance from the teacher, yet they were still under control. In the conventional class, real competition was invertible. Both high and low academic ability students tried to get higher results. Indeed, the progress of metacognitive skills' improvement on students in low academic ability was not significant. Therefore, students with high metacognitive skills could be successful on academic performances

\section{CONCLUSION}

The findings offer the following conclusion: open inquiry learning was more potential to facilitate high metacognitive skills in high and low academic abilities of students rather than conventional method. The metacognitive skills of students with high academic ability were higher than those students with low academic ability. However, the interaction of the learning models and academic abilities in this study showed no significant difference of metacognitive skills.

\section{RECOMMENDATION}

There were the recommendations of this study. Firstly, teacher should be able to design observable concept related to the topic which will be learned. In open inquiry, the instructions for the next activity should be provided in the end of last teaching period or couple days before learning activity that aims to simplify low-ability students as they need more time to make preparations than high-ability students. Secondly, although open inquiry refers to high student-centered learning; teacher is still the key factor in classroom. Teacher should have the attitudes and skills to support students becoming successful inquiry-basic learner. Teacher must trust that students have some elements of manage over what they will do and how can they behave it. For example, giving respond by paraphrasing on repetition what they have expressed without praising and criticizing that aims to drive students thinking and stop to expect validation from the teacher. Lastly, in low ability students open inquiry was very inconvenient method to directly apply. Hence, adaptation and modification is needed to help low ability students, for instance, supply them with some general procedures in the first learning period or let students watching the example or attempt the activity before learning activity in the classroom. These will eventually lead students to true inquiry. In addition, in the learning activity teacher has to concern in the process of grouping and class management to maximize knowledge transfer from high to low academic ability.

Many teachers have stated that students mostly refuse open-ended instruction, but after several learning periods they gain to like it and respect its value. Science education 
research community in Welch, Klopfer, Aikenhead, and Robinson (1981) also showed how to create and manage inquiry-based learning in classroom, and clarify that open inquiry is not only for bright kids but also for all academic levels of students. To help both middle and low-level students benefit to inquiry-based learning, they mentioned some recommendations namely: (1) the activity should be around questions that student directly can respond through investigation. (2). Emphasizing situations familiar to students and learning activity using materials. (3) Selecting appropriate activities based on student's skills and familiarity. However, the caveat of those recommendations that too difficult activity would not make students learns the content effectively. On the other hand, the students will not increase their thinking skills if the activity is too simple. The appropriate learning is if the activity is cognitively challenging, but still workable (Colburn, 2000).

\section{REFERENCES}

Anderson, L. W., Krathwohl, D. R., Airasian, P., Cruikshank, K., Mayer, R., Pintrich, P., . . . Wittrock, M. (2001). A taxonomy for learning, teaching and assessing: A revision of Bloom's taxonomy. New York. Longman Publishing. Artz, AF, \& ArmourThomas, E.(1992). Development of a cognitive-metacognitive framework for protocol analysis of mathematical problem solving in small groups. Cognition and Instruction, 9(2), 137-175.

Antika, L. T., Corebima, A. D., \& Mahanal, S. (2013). Perbandingan Keterampilan Metakognitif, Hasil Belajar Biologi, dan Retensi Antara Siswa Berkemampuan Akademik Tinggi dan Rendah Kelas X SMA Di Malang Melalui Strategi Problem Based Learning (PBL). SKRIPSI Jurusan Biologi-Fakultas MIPA UM.

Arikunto, S. (2001). Disiplin belajar/discipline of learning. Jakarta: PT. Rineka Cipta Rajawali Pers.

Bahri, A. (2018). Beyond effective teaching: Enhancing students' metacognitive skill through guided inquiry. Paper presented at the Journal of Physics: Conference Series.

Bonnstetter, R. J. (1998). Inquiry: Learning from the past with an eye on the future. Electronic Journal of Science Education, 3(1).

Bransford, J. D., Brown, A., \& Cocking, R. (2000). How people learn (Expanded ed.). Washington, DC: National Academy.

Brown, A. L., \& DeLoache, J. S. (1978). Skills, plans, and self-regulation. Children's thinking: What develops, 3-35.

Cangelosi, D. M., \& Schaefer, C. E. (1991). A twenty-five year follow-up study of ten exceptionally creative adolescent girls. Psychological reports, 68(1), 307-311.

Chickering, A. W., \& Gamson, Z. F. (1987). Seven principles for good practice in undergraduate education. AAHE bulletin, 3, 7.

Colburn, A. (2000). An inquiry primer. Science scope, 23(6), 42-44. 
Council, N. R. (2000). Inquiry and the national science education standards: A guide for teaching and learning: National Academies Press.

Danoebroto, S. W. (2008). Improving Problem Solving Skill Using The PMRI and Metacognitive Training. Jurnal Penelitian dan Evaluasi Pendidikan, Nomor, 1.

Eggen, P., Kauchak, D., \& Harder, R. (1996). Strategy for Teacher: Boston: Elly and Bacon.

Glaser, R. (1990). The reemergence of learning theory within instructional research. American psychologist, 45(1), 29.

Jonassen, D. H. (2011). Ask systems: Interrogative access to multiple ways of thinking. Educational Technology Research and Development, 59(1), 159-175.

Knodt, J. S. (2009). Cultivating curious minds: teaching for innovation through openinquiry learning. Teacher Librarian, 37(1), 15.

Kuhlthau, C. C. (2010). Guided inquiry: School libraries in the 21st century. School Libraries Worldwide, 16(1), 1.

Lee, C., Ng, M., \& Phang, R. (2002). Effects of cooperative learning on elementary school children in Singapore. Asia Pacific Journal of Education, 22(1), 3-15.

Lyman, L.-F., \& Harvey, C. (1988). Cooperative Learning Strategies and Children. ERIC Digest.

Peters, M. (2000). Does constructivist epistemology have a place in nurse education? Journal of nursing education, 39(4), 166-172.

Prayitno, B. A. (2011). Pengembangan perangkat pembelajaran IPA Biologi SMP berbasis inkuiri terbimbing dipadu kooperatif STAD serta pengaruhnya terhadap kemampuan berpikir tingkat tinggi, metakognisi, dan keterampilan proses sains pada siswa berkemampuan akademik atas dan bawah. Universitas Negeri Malang.

Roth, W.-M. (2012). Authentic school science: Knowing and learning in open-inquiry science laboratories (Vol. 1): Springer Science \& Business Media.

Suratno, S. (2011). Teacher's Work Culture to Realize High Quality of Islamic School (Site Study at MTs. Qodiriyah Harjowinangun Dempet Demak). Universitas Muhammadiyah Surakarta.

Suratno, T. (2009). Lesson study in Indonesia: the case of Indonesia university of education. Paper presented at the World Association of Lesson Studies International Conference, Hong Kong Institute of Education, Hong Kong.

Veenman, M. V., \& Elshout, J. J. (1994). Differential effects of instructional support on learning in simultation environments. Instructional science, 22(5), 363-383.

Welch, W. W., Klopfer, L. E., Aikenhead, G. S., \& Robinson, J. T. (1981). The role of inquiry in science education: Analysis and recommendations. Science education, 65(1), 33-50. 
Woolfolk, A. (2014). Education Psychology (twelft edition ed.). United States of America: Pearson New International Edition.

Yerrick, R. K. (2000). Lower track science students' argumentation and open inquiry instruction. Journal of Research in Science Teaching, 37(8), 807-838.

Zion, M., \& Mendelovici, R. (2012). Moving from structured to open inquiry: Challenges and limits. Science Education International, 23(4), 383-399.

Zion, M., \& Slezak, M. (2005). It takes two to tango: In dynamic inquiry, the selfdirected student acts in association with the facilitating teacher. Teaching and Teacher Education, 21(7), 875-894. 